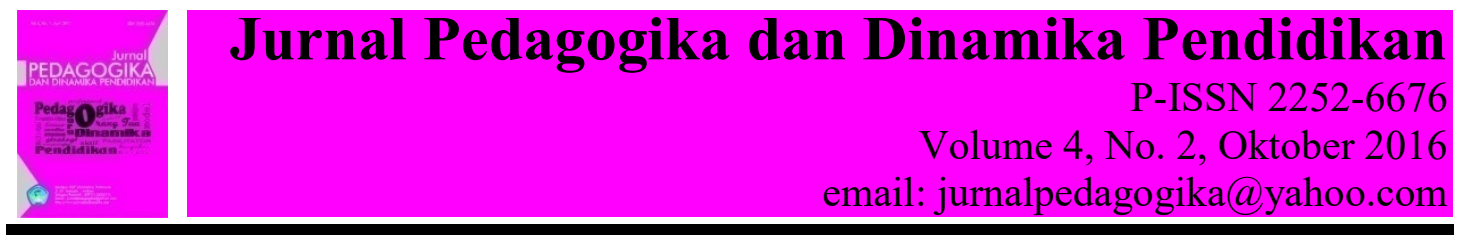

\title{
TRANSFORMATIVE LEARNING DALAM KEGIATAN PERKULIAHAN DI PROGRAM STUDI PENDIDIKAN LUAR SEKOLAH UNIVERSITAS PATTIMURA AMBON
}

\author{
Junita Liliana Kundre \\ Fakultas KIP Universitas Pattimura Ambon \\ E-mail : kundrej@yahoo.com
}

\begin{tabular}{l} 
ARTICLE INFO \\
\hline Article History: \\
Accepted 25 September 2016 \\
Available online 28 Oktober \\
2016 \\
\hline
\end{tabular}

Keywords:

Transformative learning, pendidikan luar sekolah.

\begin{abstract}
Pembelajaran transformatif yang terjadi pada kegiatan perkuliahan di mata kuliah Konflik dan Integrasi Sosial dan Kehidupan Masyarakat Multikultural di prodi PLS Unpatti Ambon, tujuan penelitian untuk menganalisis gambaran umum transformative learning dalam kegiatan perkuliahan di mata kuliah Konflik dan Integrasi Sosial dan Kehidupan Masyarakat Multikultural di prodi PLS, masalah-masalah yang dihadapi mahasiswa dikedua mata kuliah tersebut, tindakan-tindakan transformatif seperti apa yang dilakukan oleh para dosen dalam mengatasi permasalahan yang dihadapi mahasiswa, bagaimana dampak perubahan yang dialami oleh mahasiswa setelah memperoleh pembelajaran transformatif. Hasil penelitian : (1) Pembelajaran transformatif pada kedua mata kuliah ini mahasiswa dapat memiliki kemampuan mengaplikasikan nilai-nilai sosial budaya, dan mengubah persepsi atau cara pandang peserta didik dalam kehidupan sehari-hari sebagai masyarakat kampus ataupun sebagai masyarakat umum, serta memiliki kompetensi untuk memahami pendidikan multikultural sebagai upaya pemahaman keberagaman. (2) Konflik Sosial yang terjadi beberapa tahun lalu di Maluku, sudah jelas dapat mempengaruhi karakter para mahasiswa prodi PLS Unpatti Ambon dengan memiliki pemikiran-pemikiran yang negatif terhadap teman yang lain. (3) Pada mata kuliah Konflik dan Integrasi Sosial dalam kegiatan perkuliahan melalui kegiatan diskusi, curah pendapat, pembagian tugas-tugas kuliah berupa pribadi dan kelompok dengan menggunakan model ekspositori, selanjutnya mata kuliah Kehidupan Masyarakat Multikultural dengan menggunakan pembelajaran cooperative learning. (4) Dampak perubahan yang dialami oleh mahasiswa prodi PLS Unpatti Ambon, yang mana berpengaruh pada kognitif, afektif dan psikomotorik. Yang mana berpengaruh pada pengetahuan yaitu mahasiswa sudah dapat mengetahui cara-cara pengendalian konflik dan menghindari konflik serta dalam kehidupan bermasyarakat kita sangat membutuhkan orang lain. Selanjutnya pada perubahan sikap, para mahasiswa sudah dapat membuka diri dan menerima kekurangan orang lain dan saling menghormati tanpa membedakan darimana orang itu berasal.
\end{abstract}




\section{PENDAHULUAN}

Seperti diketahui bahwa salah satu proses pembelajaran yakni pembelajaran transformatif (transformative learning) yang merupakan teori belajar yang unik, abstrak, dan ideal dengan puncaknya yang disebut critical reflection (renungan kritis). Dalam setting pendidikan non-formal dan informal, dari filosofi humanistik lahir dari teori transformative learning sebagai teori pembelajaran yang paling berkembang dewasa ini, Jarvis (2004). Kemampuan untuk mengubah diri sampai pada tingkat kesadaran dan mindset akhirnya diurus oleh pembelajaran transformatif. Selanjutnya penelitian terdahulu pada penelitian yang lebih awal pada refleksi dengan pembelajaran transformatif difokuskan terutama untuk mengidentifikasi hubungan serta kemunculan refleksi pada pembelajaran transformatif (Taylor, 1988). Cranton dan Carusetta (2004:20-21), yang didasarkan pada penelitian seksama pada keaslian mengajar telah ditemukan para pendidik yang secara kritis merefleksikan kepada "diri sendiri, orang lain, hubungan-hubungan dan keadaan yang cenderung menunjukan keaslian". Dengan penelitian yang lebih lanjut, "keaslian" mungkin dapat ditemukan sebagai hasil yang lain dari refleksi yang kritis secara terus menerus.

Transformation itu pada dasarnya adalah suatu proses yang menghasilkan perubahan yang berbeda pada sesuatu hal dari bentuk, corak, atau sifatnya yang semula. Hal itu juga berarti pembentukan secara lintas. Jadi proses itu mesti menghasilkan perubahan dan perubahannya tidak sekedar perubahan yang biasa dalam arti perubahan dalam hal gradasi atau tingkat yang bentuk, corak, sifat atau bahkan jenisnya masih tetap seperti sebelumnya. Jadi suatu perubahan pemahaman dalam arti terjadi peningkatan bukanlah transformasi.

Proses ini bisa terjadi di dalam diri seseorang tanpa bantuan orang lain atau bahkan stimulus lingkungan (semata-mata oleh proses psikologisnya), dan bisa juga karena dorongan suatu stimulus termasuk orang lain baik secara disengaja ataupun tak disengaja. Hal itu juga bisa terjadi oleh upaya seseorang itu sendiri dalam suatu kegiatan belajar yang sengaja dilakukannya secara mandiri. Oleh karena itu peristiwa transformasi bisa terjadi dalam setting pendidikan informal, non-formal maupun formal.

Dengan kata lain, transformative learning itu bisa merupakan proses belajar dan bisa pula proses pembelajaran. Disebut proses belajar jika hal itu terjadi tanpa adanya intervensi pihak lain, dan disebut proses pembelajaran jika terjadinya disebabkan oleh kesengajaan orang lain. Proses belajar itu sendiri bisa terjadi baik disengaja maupun tidak disengaja.

Pembelajaran transformatif berarti upaya pendidik untuk mengubah persepsi, pendapat, anggapan, minat, sikap, pola pikir, ataupun keyakinan peserta didik dalam rangka mengembangkan potensinya untuk memecahkan masalah kehidupan yang sedang di hadapinya. Terkait dengan konflik sosial yang pernah terjadi di provinsi Maluku pada tahun 1999-2002 sehingga menyisahkan luka yang dalam bagi masyarakat kota Ambon, serta menyuramkan masa depan rakyat Maluku.

Nilai-nilai Pancasila sepertinya sudah luntur dalam masyarakat kita, itu dari maraknya pelaku tindakan korupsi, kekerasan, dan kendurnya nasionalisme. Oleh karena itu perlu membentuk karakter bangsa Indonesia yang sesuai dengan nilai-nilai 
Pancasila harus dilakukan sejak usia dini melalui dunia pendidikan yakni, pendidikan karakter dalam semangat kearifan lokal, semasa menjadi peserta didik (mahasiswa) kami cenderung memilih 'jalur bebas', organisasi-organisasi ekstrakampus untuk berkegiatan tidaklah tersedia seperti yang terjadi di kebanyakan kampus-kampus yang terkemuka di pulau Jawa. Kami hanya mempunyai ruang kelas dan papan tulis untuk kegiatan perkuliahan. Terkenang sebuah pernyataan gamblang dari seorang guru besar di awal masa kuliah "terima kasih" untuk kalian yang telah memilih berkuliah di sini, di tengah keterbatasan sarana dan prasarana yang ada. Bila suatu hari kalian berhasil, percayalah bahwa hal tersebut bukanlah karena kampus menjadikan kalian seperti itu, tetapi karena kalian lahir dengan memiliki kecerdasan, memiliki sikap yang bertanggung jawab, suka menghormati dan memiliki kesadaran diri.

Kenyataan yang dihadapi kini ke depan makin kompleks dan pluridimensional; membutuhkan solusi holistik dan konvergensi. Bagi Program Studi Pendidikan Luar Sekolah FKIP Unpatti, para pendidik/tutor (dosen) PLS tidak hanya dituntut untuk menguasai bidang yang diajarkan. Melainkan juga mampu membantu peserta didik (mahasiswa) mengembangkan dirinya sebagai Citra Tuhan (Imago dei), melalui penguasaan materi-materi kuliah pada pembelajaran transformatif.

\section{METODE}

\section{Pendekatan dan Jenis Penelitian}

Penelitian ini menggunakan pendekatan kualitatif, dengan pertimbangan bahwa penelitian ini ingin memperoleh gambaran tentang proses pembelajaran dalam kegiatan perkuliahan di program studi Pendidikan Luar Sekolah Universitas Pattimura Ambon secara apa adanya selama kegiatan perkuliahan berlangsung. Desain penelitian yang digunakan adalah studi kasus dimana lebih menekankan pada pengungkapan secara dan mendalam terhadap suatu objek, peristiwa atau kejadian dalam penelitian ini substansi kasus yang digali adalah tentang transformative learning. Penelitian ini dilaksanakan pada mahasiswa semester 6 konsentrasi sosiologi program studi Pendidikan Luar Sekolah beserta para dosen yang mengasuh mata kuliah Konflik dan Integrsi Sosial dan mata kuliah Kehidupan Masyarakat Multikultur.

Dalam melaksanakan penelitian ini, data dikumpulkan terkait dengan fokus penelitian yaitu transformative learning yang terjadi didalam kegiatan perkuliahan di program studi Pendidikan Luar Sekolah Universitas Pattimura Ambon. Data diperoleh melalui wawancara, observasi, dan dokumentasi.

Pengumpulan data penelitian kualitatif menuntut peran peneliti sebagai instrument. Peneliti memulai mengumpulkan data penelitian awal bulan Maret 2013 yakni dengan mendatangi ketua program studi dan para mahasiswa prodi PLS Unpatti Ambon. Penelitian ini dilakukan di kampus PGSD FKIP Unpatti Ambon, pemilihan lokasi kampus PGSD FKIP Unpatti Ambon adalah didasari karena para mahasiswa prodi PLS Unpatti terbuka untuk dilakukan penelitian dan memiliki hubungan emosional dengan pihak prodi PLS sangat baik sehingga memungkinkan terjadinya kerjasama (berkolaborasi) dengan baik. 
Data yang dikumpulkan adalah data yang berkaitan pada fokus penelitian, sumber data dalam penelitian ini adalah para dosen yang mengetahui informasi yang dibutuhkan dan yang berperan langsung dalam kegiatan perkuliahan. Sumber data lain yaitu para mahasiswa. Sedangkan untuk data non manusia adalah dokumendokumen yang relevan dengan fokus penelitian serta sumber data pendukung lainnya berupa dokumentasi dan arsip yang berkaitan dengan transformative learning dalam perkuliahan di prodi PLS.

Dalam penelitian ini, analisis data yang dipergunakan adalah interactive models (Miles \& Huberman, 1994:12) dimana aktivitas dalam analisis data kualitatif dilakukan secara interaktif dan berlangsung secara terus-menerus sampai tuntas, sehingga mengalami kejenuhan data. Aktivitas dalam analisis data, yaitu data collection, data reduction, data display, dan conclusions: drawing/verification. Keabsahan data pada penelitian kualitatif merupakan faktor yang sangat penting. Hal ini berkaitan dengan tanggung jawab ilmiah terhadap hasil penemuan dalam penelitian.

Untuk menetapkan keabsahan data hasil penelitian tersebut, Sugiyono (2011: 270) menyatakan empat kriteria yang digunakan dalam penelitian kualitatif, yaitu: (a) derajat kepercayaan dalam rangka membuktikan temuan hasil penelitian dengan kenyataan yang diteliti di lapangan. Teknik-teknik untuk membuktikan kebenaran penelitian dengan cara perpanjangan pengamatan, peningkatan ketekunan, triangulasi (sumber data dan teknik), diskusi dengan teman sejawat, analisis kasus negatif, dan memberchack; (b) keteralihan (transferability), dimana proses ini menunjukkan derajat ketepatan atau dapat diterapkan hasil penelitiannya ke populasi dimana sampel itu diambil sehingga penelitian ini dapat dipercaya; (c) kebergantungan (dependability), dimana suatu penelitian yang reliable adalah apabila orang lain dapat mengulangi/mereplikasi proses penelitian tersebut; dan (4) kepastian (confirmobility), dimana penelitian dikatan objektif bila hasil penelitian telah disepakati oleh banyak orang.

\section{Tahap-tahap Penelitian}

Dalam melaksanakan penelitian ini, peneliti menggunakan tahap-tahap penelitian menurut Moleong (2010:127) sebagai berikut. Ada tujuh tahapan kegiatan yang dilakukan dalam tahap pra-lapangan yaitu: (a) menyusun rancangan penelitian; (b) memilih lapangan penelitian; (c) mengurus perizinan untuk mengadakan penelitian; (d) menjajaki dan menilai lapangan; (e) memilih dan memanfaatkan informan; (f) menyiapkan perlengkapan penelitian; (g) persoalan etika penelitian. Ada empat tahapan kegiatan yang dilakukan dalam tahap pekerjaan lapangan antara lain sebagai berikut: (a) peneliti melakukan pendekatan dengan program studi Pendidikan Luar Sekolah FKIP Unpatti Ambon dalam hal ini Ketua Program Studi Pendidikan Luar Sekolah ; (b) peneliti melakukan pengumpulan data dengan cara wawancara, observasi, dan dokumentasi mengenai hal-hal yang dianggap menarik, penting, dan berguna untuk diteliti; (c) melakukan memberchek, kegiatan ini dilakukan secara berulang-ulang baik data hasil wawancara maupun observasi; dan (d) tahap pelaporan, dimana setelah data terkumpul, kemudian data dianalis, maka tahap 
pelaporan dilaksanakan bersamaan dengan penyusunan tesis sesuai dengan analisis yang telah diuraikan di atas.

\section{HASIL DAN PEMBAHASAN}

Gambaran Umum Transformative Learning Dalam Kegiatan Perkuliahan di Mata Kuliah Konflik dan Integrasi Sosial dan Kehidupan Masyarakat Multikultur di Prodi PLS

Konflik berasal dari kata kerja Latin configere yang berarti saling memukul. Secara sosiologis, konflik diartikan sebagai suatu proses sosial antara dua orang atau lebih (bisa juga kelompok) dimana salah satu pihak berusaha menyingkirkan pihak lain dengan menghancurkannya atau membuatnya tidak berdaya. Konflik dilatarbelakangi oleh perbedaan ciri-ciri yang dibawa individu dalam suatu interaksi. Perbedaan-perbedaan tersebut diantaranya adalah menyangkut ciri fisik, kepandaian, pengetahuan, adat istiadat, keyakinan, dan lain sebagainya. Konflik yang muncul dalam masyarakat yang merupakan akibat adanya perbedaan kepribadian, persepsi, pengalaman, tujuan, motivasi ataupun kepercayaan tiap anggota masyarakat yang saling berinteraksi dalam kehidupan bermasyarakat. Tak dapat disangkal lagi apabila hingga kini kita makin akrab dengan konflik. Namun kini kita tak perlu lagi merasa takut dan ngeri mendengarnya. Karena, ternyata konflik yang terjadi tidak selamanya membawa akibat buruk sepanjang dapat dikelola dengan baik. Justru dengan adanya konflik akan memacing daya kreasi dan inovasi anggota masyarakat baik secara individu maupun secara kolektif. Banyak cara ataupun strategi yang dapat diterapkan untuk mengatasi dan bahkan mengurangi sensitivitas masyarakat terhadap pemicu konflik potensial diantara mereka. Berbagai macam training, seperti sensitivity training, diversity training program ataupun cross-cultural training (Noe, Hollenbeck, Gerhart, Wright, 2000:254), dapat dilakukan untuk menjawab masalah konflik sehingga sumber daya manusia dalam kehidupan bermasyarakat dapat memberikan manfaat yang lebih besar.

Selanjutnya secara konsepsional, pendidikan multikultural adalah pendidikan yang mengakui adanya kemajemukan dalam masyarakat, bahwa ada banyak budaya, sistem nilai, adat-istiadat dan juga bahasa. Mencermati batasan tersebut, sebenarnya selama ini kita mengakui itu. Dalam tataran nasional (makro) paling tidak tercermin dari prinsip Bhineka Tunggal Ika. Dalam tataran mikro, (wilayah Maluku misalnya) dikenal dengan budaya salah satunya adalah budaya "Pela Gandong" yang mana secara kultural, orang Maluku bersaudara; contohnya marga-marga yang ada pada saudara pemeluk agama muslim sama dengan marga yang ada pada saudara pemeluk agama nasrani, contoh yang lain adalah acara pelantikan kepala desa saudara muslim saudara nasrani tidak ketinggalan turut berperan serta datang dari desa tetangga dengan membawa hasil-hasil kebun mereka, membuat tenda atau bahasa hari-hari di ambon "sabua", memasak di dapur bahkan menginap di kampung tempat pelantikan kepala desa tersebut hingga acara tersebut selesai barulah mereka kembali ke desa mereka. Hal tersebut menunjukan bahwa walaupun berbeda agama dan kepercayaan tetapi mereka adalah orang bersaudara karena mereka berasal dari satu garis keturunan. Hal tersebut benar-benar ada di semua kabupaten kota di Maluku. 
Walaupun beragam corak dan budaya tetapi setiap orang Maluku diberi ruang dan kebebasan untuk hidup menurut budaya dan kepercayaannya.

Pembelajaran transformatif pada perkuliahan dengan mengunakan kegiatan motivasional yang dilaksanakan bagi mahasiswa semester 6 konsentrasi Sosiologi angkatan 2010 program studi PLS yang mana diatur sesuai dengan kurikulum program studi PLS pada jadwal kuliah semester genap yakni mata kuliah Kehidupan Masyarakat Multikultur dan mata kuliah Konflik dan Integrasi Sosial dengan bobot sks 3. Pada masing-masing mata kuliah ini diatur sesuai dengan jadwal perkuliahan yakni pada hari rabu dan kamis.

\section{Masalah-Masalah Yang dihadapi Mahasiswa dikedua Mata Kuliah}

Pendidikan merupakan jalur normalitas sosial yang utama. Lewat jalur pendidikanlah proses rekayasa sosial itu berlangsung. Melalui pendidikan peserta didik tidak saja ditempa pengetahuan akademisnya, diperkuat vokasinya akan tetapi dibentuk kepribadiannya sehingga menjadi insan yang bermoral, berkepribadian Indonesia, menghargai pluralisme dan mampu bersaing dalam percaturan global. Aksentuasi kegiatan pembelajaran kita lebih terfokus pada learning to think dan learning to do. Sedangkan learning to be dan learning to live together cenderung terabaikan. Para pendidik kita lebih terinspirasi mengejar capaian yang sifatnya kuantitatif. Sehingga masalah yang sering dialami oleh peserta didik tidak dapat diselesaikan dengan baik, salah satu contoh ialah pada para peserta didik yang berada pada program studi PLS Unpatti Ambon.

\section{Tindakan-Tindakan Transformatif Yang Dilakukan Oleh Para Dosen Dalam Mengatasi Permasalahan Yang dihadapi Dengan Pembelajaran Transformatif}

Kebutuhan hidup manusia sangat beragam. Ada kebutuhan fisik, seperti sandang, pangan, dan papan. Ada pula kebutuhan psikis yang mesti dipenuhi agar jiwa kita bahagia. Selain itu, manusia juga memerlukan kebutuhan hidup sosial, misalnya pertemanan, kerjasama, bahkan sampai kompetisi dan konflik. Untuk memenuhi semua kebutuhan tersebut manusia melakukan tindakan-tindakan tertentu. Tindakan manusia disesuaikan dengan nilai dan norma sosial yang berlaku di masyarakat.

Dalam khazanah sosiologi, pengertian tindakan sosial di atas dipengaruhi oleh definisi Max Weber. Max Weber seperti dikutip oleh G. Ritzer (1992) mengartikan tindakan sosial sebagai tindakan manusia yang dapat memengaruhi individu-individu lainnya dalam masyarakat. Pemikiran Max Weber itu berbeda dengan pemikiran sosiolog lainnya. Emile Durkheim seperti dikutip oleh G. Ritzer (1992) menunjuk tindakan sosial sebagai perilaku manusia yang diarahkan oleh norma-norma dan tipe solidaritas kelompok tempat ia hidup.

Sementara itu, pemikir besar Karl Marx seperti dikutip oleh G. Ritzer (1992) mengartikan tindakan sosial sebagai aktivitas manusia yang berusaha menghasilkan barang, atau mencoba sesuatu yang unik, maupun untuk mengejar tujuan tertentu. 
Seperti di ketahui bahwa dalam setiap proses perkuliahan yang berlangsung para pendidik selalu menggunakan metode-metode atau prosedur-prosedur yang berupa ceramah, tanya jawab, diskusi kelompok dan penggunaan LCD berupa power point. Dalam proses pembelajaran seputar permasalahan yang dialami oleh peserta didik baik secara langsung maupun tidak langsung para pendidik dengan cermat memperhatikan dengan baik sehingga ada hubungan timbal-balik. Selain itu juga dalam memberikan materi-materi perkuliahan selalu diimbangi dengan kata-kata yang memberikan motivasi bagi peserta didik sehingga para peserta didik dapat merasakan sesuatu hal yang baru dalam pola berpikir, cara pandang mereka yang mana pada saat diskusi menjawab pertanyaan-pertanyaan dengan baik dan benar.

\section{Dampak Perubahan Yang dialami Oleh Mahasiswa Setelah Memperoleh Pembelajaran Transformatif}

Dalam konteks pembelajaran transformatif peserta didik tidak sekedar menjadi obyek pembelajaran yang siap disuguhkan berbagai pengetahuan akademik, akan tetapi menjadi subyek yang perlu diberi motivasi dan animasi, disentuh emosi dan perasaannya. Peserta didik tidak semata-mata belajar atau menghafal tentang sesuatu (konsep) atau rumus, akan tetapi dikondisikan untuk memaknai lebih jauh hakekat dan makna sesungguhnya dari apa yang dipelajari. Dengan kata lain, melakukan penjelajahan intelektual mengenai tata nilai, yakni makna hidup dan kehidupan. Sejalan dengan itu Bernadib (1988) dari perspektif Filsafat esesnsialis mengemukakan bahwa ontologi pendidikan adalah pemeliharaan nilai-nilai pokok yang bersifat konstan dan jelas dapat dianggap mendatangkan kestabilan. Nilai-nilai pokok dimaksud oleh Hamdani (1990) adalah nilai-nilai lama yang telah ada semenjak peradaban manusia, yang telah teruji dan berbuah kebajikan untuk kepentingan manusia.

Melalui proses mendidik, nilai-nilai tersebut direvitalisasi sehingga mempengaruhi pola pikir, sikap dan perilaku peserta didik. Itulah gambaran dasar dari perbuatan mendidik yang oleh Driyarkara, (2006) disebut dengan istilah "Memanusiakan Manusia Muda". Selanjutnya Driyarkara mengemukakan bahwa nilai harus dialami, dilaksanakan dalam hidup yang konkrit. Sebelum menjadi kebenaran yang dipikir, sudah menjadi verite vecue, kebenaran yang dialami. Dalam pengalaman yang konkrit gambaran itu bukanlah sesuatu, melainkan pribadi pendidik dan pribadi peserta didik yang bertemu dalam kesatuan Ich $u n d u$, dalam pertemuan yang mendalam di mana aku dari pendidik dan aku dari peserta didik bersatu menjadi kita yang mengangkat aku peserta didik ke tingkat aku pendidik. Pengangkatan ini oleh Driyarkara disebut hominisasi dan humanisasi.

\section{SIMPULAN DAN SARAN}

\section{Simulan}

(1)Gambaran umum transformative learning dalam kegiatan perkuliahan di mata kuliah Konflik dan Integrasi Sosial dan Kehidupan Masyarakat Multikultural di prodi PLS, Dalam proses pembelajaran transformatif pada kegiatan perkuliahan yang diberikan oleh para dosen, selain materi-materi perkuliahan juga diadakannya bentuk- 
bentuk permainan motivasi yang mengandung berbagai nilai-nilai sosial budaya, salah satunya adalah permainan jaring laba-laba yang dibagi atas tiga kelompok dengan nama-nama kelompok yang berasal dari daerah kabupaten/kota yaitu: kelompok Masohi (nama kelompok berasal dari kabupaten Maluku Tengah); saling gotong-royong, kelompok Badati (nama kelompok berasal dari kabupaten Seram Bagian Timur); saling membantu, saling bahu-membahu dalam integrasi, kelompok Maren (nama kelompok berasal kabupaten Maluku Tenggara); saling kerjasama. Sehingga dalam kegiatan perkuliahan memberikan pengaruh bagi para dosen dan mahasiswa prodi PLS konsentrasi sosiologi angkatan 2010, pada cara pandang dalam pola berpikir secara konfrehensif, holistik, atau secara menyeluruh berdasarkan pendekatan orang dewasa serta didalam kehidupan berbangsa, bernegara dan berbudaya kita harus saling menghormati, saling keterbukaan, saling memberikan support dan saling berbagi baik diantara para dosen maupun mahasiswa didalam berbagai hal, baik dalam dunia kampus maupun kehidupan bermasyarakat; (2) Masalah-masalah yang dihadapi mahasiswa dikedua mata kuliah, Konflik sosial yang terjadi di provinsi Maluku kota Ambon beberapa tahun lalu sangat mempengaruhi pola pikir, cara pandang dan cara bertindak didalam proses pembelajaran yang terjadi. Sudah jelas dapat mempengaruhi karakter kita salah satunya adalah pada mahasiswa prodi PLS FKIP Unpatti. Yang tadinya saling curiga, tidak bersahabat, suka menyendiri, berprasangka buruk satu terhadap yang lain, dan menutup diri. Namun dalam proses pembelajaran yang diberikan oleh pendidik melalui kegiatan perkuliahan dengan mempergunakan metode-metode pembelajaran sehingga secara perlahan-lahan peserta didik itu sendiri menyadari bahwa didalam kehidupan kita sebagai masyarakat kampus harus tetap menjaga keharmonisan, toleransi, saling memberikan penguatan melalui kata-kata motivasi yang sering kita dengar bahwa perbedaan itu indah seperti pelangi walaupun berbeda warna dan corak tetap sedang dipandang kita pun demikian walaupun berbeda dari segi agama, suku, dan ras tetapi didalam keegiatan perkuliahan didalam membahas tugas-tugas kelompokpun kita harus tetap menjaga keharmonisan dan saling memberikan penguatan dengan kata-kata motivasi; (3) Tindakan-tindakan transformatif yang dilakukan oleh para dosen dalam mengatasi permasalahan yang dihadapi mahasiswa, pembelajaran transformatif yang dilakukan dalam bentuk perkuliahan yang diperuntukkan bagi peserta didik program studi PLS angkatan 2010 semester 6 konsentrasi sosiologi, yakni para dosen menggunakan bahan ajar sebagai pegangan bagi pendidik, diskusi perkelompok, bentuk-bentuk permainan motivasi, bahkan curah pendapat tentang masalah-masalah yang terkait dengan materi-materi perkuliahan. Pada mata kuliah Konflik Dan Integrasi Sosial menggunakan pendekatan ekspositori dan mata kuliah Kerhidupan Masyarakat menggunakan pendekatan cooperative learning. Dalam setiap perkuliahan para pendidik selalu menggunakan kata-kata motivasi seperti perbedaan itu indah, untuk itu dalam dunia pendidikan tidak ada perbedaan antara mahasiswa yang satu dengan mahasiswa yang lain. Karena kita sudah dirangkul dalam Bhinneka Tunggal Ika yakni berbeda-beda tetap satu dengan memiliki dasar negara yakni Pancasila ; (4) Dampak perubahan yang dialami oleh peserta didik setelah memperoleh pembelajaran transformatif, Perubahan belajar 
kognitif, afektif dan psikomotor merujuk pada taksonomi yang dibuat untuk tujuan pendidikan. Taksonomi ini pertama kali disusun oleh Benjamin S. Bloom pada tahun (1956). Belajar kognitif adalah belajar yang berkaitan dengan aspek intelektual. Yang mana sebagai mahasiswa dapat memiliki kompetensi meliputi: pemahaman, mengaplikasikan, menganalsis, mensitesakan dan menilai pengalaman belajar. Pengalaman belajar untuk tingkat pemahaman dilakukan dengan membandingkan, mengidentifikasikan karakteristik dan sebagainya. Berkaitan dengan afektif, pengalaman belajar yang perlu dilakukan agar peserta didik dalam sikap dan perilaku memiliki minat dan perhatian dalam proses pembelajaran transformatif dapat berpartisipasi aktif sesuai dengan tuntutan nilai yang dipelajari dan sebagainya.

Untuk psikomotorik, pengalaman belajar yang dapat dilakukan oleh para mahasiswa prodi PLS Unpatti untuk mencapai kompetensi ini salah satunya adalah berlatih untuk mengeluarkan pendapat dengan mempergunakan kata-kata yang sopan dalam etika berkomunikasi, dan dalam memberikan argumen tidak menyinggung perasaan teman yang lain dengan tidak menganggap dirinya lebih hebat dari teman yang lain. Beberapa istilah lain yang juga menggambarkan hal yang sama dengan ketiga domain tersebut di antaranya seperti yang diungkapkan oleh Ki Hajar Dewantoro yaitu: cipta, rasa, dan karsa. Selain itu, juga dikenal istilah: penalaran, penghayatan, dan pengamalan.

Saran

(1) Bagi pihak program studi PLS Unpatti Ambon hendaknya lebih giat meningkatkan kualitas penyelenggaraan pendidikan pada tingkat program studi agar dapat menghasilkan lulusan tenaga pendidik dan kependidikan yang profesional, berkualitas, bermoral, memiliki daya saing tinggi. Dan menjadikan program studi sebagai pusat layanan pendidikan, penelitian, dan pengabdian pada masyarakat dalam bidang Pendidikan Luar Sekolah. (2) Bagi para dosen dan mahasiswa penguasaan konsep dasar serta proses pendidikan dan pembelajaran, dan penerapannya perlu ditingkatkan dalam pelaksanaan dan pengembangan proses pembelajaran yang mendidik serta mengembangkan kepribadian dan keprofesionalan, pengembangan intuisi keagamaan dan kebangsaan yang religius dan berkepribadian, pemilikan sikap dan kemampuan mengaktualisasi diri, serta pemilikan sikap dan kemampuan mengembangkan profesional kependidikan lebih di tingkatkan. (3) Bagi peneliti selanjutnya, yang tertarik untuk melakukan penelitian tentang transformative learning hendaknya memahami secara jelas tentang teori-teori yang berkaitan dengan transformatif itu sendiri, harapan kedepannya dapat berguna dan bermanfaat.

\section{DAFTAR RUJUKAN}

Abednego dkk. 2010. Aksara Perdamaian

A.M. Sardiman. 2005. Interaksi dan Motivasi Belajar Mengajar. Jakarta: PT RajaGrafindo Persada.

Arikunto Suharsimi. 2006. Prosedur Penelitian Suatu Pendekatan Praktik, Jakarta : Rineka Cipta 
Creswell J.W. 1998. 5 Macam Tradisi Penelitian Kualitatif. Disadur oleh M. Djauzi Moedzakir. Thn 2007 Malang: Fakultas Ilmu Pendidikan Universitas Negeri Malang

Dimyati dan Mudjiono. 2006. Belajar dan Pembelajaran. Jakarta : PT. Rineka Cipta

Latif Abdul, H. 2009. Pendidikan Berbasis Nilai Kemasyarakatan. Bandung : PT. Rineka Aditama

Miles \& Huberman. 1992. Analisis Data Kualitatif, Terjemahan. Oleh Tjetjep Rohendi Rosidi. Tahun 1997. Jakarta: Penerbit Universitas Indonesia.

Moedzakir Djauzi M. 2010. Metode Pembelajaran Untuk Program-Program Pendidikan Luar Sekolah. Malang : FIP UM

Moedzakir Djauzi M. 2010. Konsep dan Strategi Pembelajaran Transformasi Untuk PLS. Download internet tanggal 04 Februari 2010.

Moleong. J Lexy. 2005. Metodologi Penelitian Kualitatif. Bandung : Remaja Rosdakarya.

Ralahalu Albert Karel dkk. 2009. Menggagas Masa Depan Maluku. Yogyakarta : Intan Cendekia

Sugiyono.2011. Metode Penelitian Kuantitatif, Kualitatif dan R\&D. Bandung: Alfabeta

---------------http://www.drzpost.com/reading-121-Teori-Tindakan-SosialMaxWeber.html

Taylor, Edward W. Penn State University-Harrisburg, AS. 1975. Pembaruan Dalam Teori Pembelajaran Transformatif: Sebuah Tinjauan Kritis Penelitian Secara Empiris (Hasil Terjemahan tanggal 4 Oktober 2012)

Universitas Negeri Malang. 2010. Pedoman Penulisan Karya Ilmiah: Skripsi, Tesis, Disertasi, Arikel, Makalah, Tugas Akhir, Laporan Penelitian. Malang : Universitas Negeri Malang

Zarkasyi, Srihadi, W. 2006. Orasi Ilmiah : Mahasiswa dan Motivasi Berprestasi. Bandung : Fakultas Ekonomi Unpad. 